\title{
The immunoregulatory mechanisms of carcinoma for its survival and development
}

Caigan Du ${ }^{1,2,3^{*}}$, Yuzhuo Wang ${ }^{1,3,4}$

\begin{abstract}
The immune system in patients detects and eliminates tumor cells, but tumors still progress persistently. The mechanisms by which tumor cells survive under the pressure of immune surveillance are not fully understood. This review is to present the evidence from clinical studies, showing a significant correlation of clinicopathological features of carcinoma with: (1) the loss of classical human leukocyte antigen class I, (2) the up-regulation of nonclassical human leukocyte antigen class I, pro-apoptotic Fas ligand and receptor-binding cancer antigen expressed on SiSo cells I, and (3) the formation of immunosuppressive microenvironment by up-regulation of transforming growth factor-beta, Galectin-1, inhibitory ligand B7s, indoleamine 2,3-dioxygenase and arginase, as well as by recruitment of tumor-induced myeloid-derived suppressor cells and regulatory T cells. All of these factors may together protect carcinoma cells from the immune-cytotoxicity.
\end{abstract}

\section{Introduction}

Carcinoma is the most commonly type of cancer transformed from epithelial cells. It has been noted for a while that the immune-mediated spontaneous regression of cancer occurs in patients [1]. Recent clinical studies have demonstrated that anti-carcinoma immunity is activated along with rise and progression of carcinoma, indicated by: (1) the tumor-infiltrating immune cells (TICs), including T, B and natural killer (NK) cells, are activated [2-4], and the number of these lymphocytes and macrophages positively correlates with cancer-specific survival rate in patients with various carcinomas [5-7]; (2) both carcinoma antigen-specific cytotoxic T lymphocytes (CTLs) [8-10] and antibodies [11-13] have been identified in cancer patients; and (3) spontaneous regression has been noted in many patients with carcinoma cancers, in which the number of infiltrating immune cells, including activated $\mathrm{CD}^{+} \mathrm{T}$ cells, NK cells, antigen presenting cells (APCs), is significantly higher than that in non-regressing controls [14-16]. Therefore, the number of infiltrating immune cells becomes a reliable biomarker for predicting cancer relapse $[17,18]$. All these studies suggest that the immune surveillance against carcinoma is active in

\footnotetext{
* Correspondence: caigan@interchange.ubc.ca

'Department of Urologic Sciences, University of British Columbia, Vancouver, BC V5Z 1M9, Canada

Full list of author information is available at the end of the article
}

patients, but how carcinoma cells still can survive and grow in some patients is not fully understood. In this review, we attempted to summarize the evidence of anti-immune functions of carcinoma from both clinical and experimental studies.

\section{Avoidance of cytotoxic lymphocyte stimulation by attenuation of human leukocyte antigen class (HLA) molecules}

Loss of HLA class I for avoidance of CD8 $8^{+}$CTL activation Classical HLA class I constitutively expresses on epithelial cells and many carcinoma cell lines, such as nonsmall cell lung cancer (NSCLC) [19]. Given a central role of HLA class I in the restriction of $\mathrm{CD}^{+} \mathrm{CTL}$ recognition of carcinoma-specific antigens, loss of HLA class I expression undoubtedly becomes a major escape pathway for the evasion of CD8 ${ }^{+}$CTL surveillance, by which any HLA class I deficient carcinoma variants can develop to more aggressive or invasive phenotypes without stimulation of primary anti-carcinoma immunity, $\mathrm{CD}^{+} \mathrm{T}$ cell response. Indeed, as listed in Table 1 , the total loss of HLA class I expression is more frequently noted with more aggressive or metastatic stages and poor differentiation phenotypes as compared to those with early stages and well to moderately differentiated lesions in patients.

A higher level of HLA class I expression in bladder carcinoma is significantly associated with a longer 
Table 1 The association of deficient HLA class I expression in carcinoma with its progression in patients

\begin{tabular}{|c|c|c|c|}
\hline $\begin{array}{l}\text { Carcinoma } \\
\text { type }\end{array}$ & $\begin{array}{l}\text { Antibodies for } \\
\text { immunohistochemical staining }\end{array}$ & Distribution of total HLA class I expression loss (\% of negative staining*) & References \\
\hline \multirow[t]{2}{*}{ Bladder } & W6/32 and GRH1 & $\begin{array}{l}\text { The altered of HLA class I including total losses associates with higher grade } \\
\text { lesions and tumor recurrence }\end{array}$ & [20] \\
\hline & A-072 & $\begin{array}{l}\text { 1) } 16.6 \% \text { in } \mathrm{G} 1,38.5 \% \text { in } \mathrm{G} 2 \text {, and } 57.1 \% \text { in } \mathrm{G} 3 \text {; } \\
\text { 2) } 5 \text {-year survival: } 74 \% \text { with positive versus } 36 \% \text { with negative staining }\end{array}$ & [21] \\
\hline Gastric & A-072 & $0 \%$ in T1 (mucosa \& submucosa) versus $100 \%$ in T2-3 (muscle and fat invasion) & [22] \\
\hline Esophageal & W6/32 & 0\%: normal and benign versus $40.5 \%$ carcinoma lesions & [23] \\
\hline Bronchogenic & W6/32 and $\mathrm{HC}-10$ & $\begin{array}{l}\text { 1) } 13 \% \text { of Diploid versus } 45 \% \text { of Aneuploid; } \\
\text { 2) } 17.3 \% \text { in G1-2 versus } 69 \% \text { in G3 }\end{array}$ & [24] \\
\hline NSCLC & W6/32 & $\begin{array}{l}\text { 1) } 26.8 \% \text { in } \mathrm{T} 1-2 \text { versus } 35 \% \text { in } \mathrm{T} 3 \text {; } \\
\text { 2) } 20.7 \% \text { in } \mathrm{G} 1-2 \text { versus } 39.3 \% \text { in } \mathrm{G} 3 \text {; } 3 \text { ) } 24.1 \% \text { in No versus } 34.5 \% \text { in } \mathrm{N} 1-2\end{array}$ & [25] \\
\hline \multirow[t]{2}{*}{ Breast } & $\mathrm{HC}-10$ & $0 \%$ in low-grade versus $67.6 \%$ in high-grade lesions & [26] \\
\hline & W6/32 & $24 \%$ in primary versus $64 \%$ in corresponding LN samples & [27] \\
\hline Pancreatic & W6/32 and 246-E8.E7 & $\begin{array}{l}\text { 1) } 6 \% \text { in primary versus } 43 \% \text { in metastastic tumors; } \\
\text { 2) } 0 \% \text { in } \mathrm{G} 1,33 \% \text { in } \mathrm{G} 2 \text { and } 67 \% \text { in } \mathrm{G} 3\end{array}$ & [28] \\
\hline Prostate & A-072 & $\begin{array}{l}\text { 1) } 0 \% \text { in Benign, } 41 \% \text { in primary and } 66 \% \text { in } L N \text { metastases; } \\
\text { 2) } 33 \% \text { in low-grade versus } 50 \% \text { in high grade lesions }\end{array}$ & [29] \\
\hline
\end{tabular}

*The cutoff line for negative staining or total loss is 5 to $25 \%$ of cells stained with antibodies. W6/32 monoclonal antibody (mAb) detects monomorphic epitope of HLA class I antigen (HLA-ABC); $246-E 8 . E 7, ~ H C-10$ and GRH1 are anti-beta2-microglobulin ( $\beta 2-m)$ mAbs; rA-270 is rabbit polyclonal anti- $\beta 2-m$ antibody (DAKO).

survival rate in patients [21], and tumors with a normal level of HLA class I harbor more $\mathrm{CD}^{+} \mathrm{T}$ cells than those with altered HLA class I in renal cell carcinomas (RCC) [30] and cervical carcinoma [31,32]. In addition, a decrease in HLA class I expression has been noted as early as in normal mucosa surrounding the tumor or in situ lesion, and is significantly associated with subsequent development to a new primary tumor lesion $[33,34]$. These data indicate that the avoidance strategy may occur at early stages of carcinoma development, and suggest that by loss of HLA class I expression to avoid $\mathrm{CD}^{+}$CTL seems critical for the development of carcinoma in patients.

\section{Heterogeneous expression of HLA class I in inactivation of NK cell cytotoxicity}

Although loss of HLA class I may benefit to carcinoma resistance to $\mathrm{CD}^{+} \mathrm{CTL}$ as discussed above, it could increase the susceptibility to cytotoxicity of natural killer (NK) cells [35] because HLA class I is a ligand for inhibitory receptor family, killer cell immunoglobulin-like receptor (KIR) of NK cells [36], Thus, loss of HLA class I expression could favor the escape of antigen-dependent cytotoxicity of $\mathrm{CD}^{+} \mathrm{CTL}$, but at the same time carcinoma cells may become a target of NK cell cytotoxicity. To date, it is not completely clear how carcinoma cells can survive under the selection of both CD8 + CTLs and NK cells simultaneously. It has been suggested that carcinoma cells find a balance between maintenance of HLA class I expression for inhibition of NK cell cytotoxicity and loss of its expression for the escape from $\mathrm{CD}^{+} \mathrm{CTL}$ responses. Indeed, the complete loss of HLA class I is barely seen in carcinomas, which may be explained by its need for inhibition of NK cell activity. The heterogeneous losses of HLA class I either positively or negatively correlate with carcinoma stages or grades in patients $[24,27,28]$, reflecting exactly the situation of carcinoma cells; if carcinoma cancer faces more severe cytotoxicity from NK cells versus $\mathrm{CD}^{+}$ CTL, certain levels of HLA class I render carcinomas resistance to NK cells; if tumor is under the pressure of $\mathrm{CD}^{+}$CTL more than NK cells, then partial loss of HLA class I becomes a key for survival, as indicated by Table 1.

In addition to heterogeneous expression of HLA class I, one has to knowledge that other strategies are seen to avoid NK cell cytotoxicity. A clinical study with oral squamous cell carcinomas shows that HLA class I expression is either weak or absent for not stimulation of $\mathrm{CD}^{+} \mathrm{CTL}$, but there is still no a clear correlation of HLA class I expression loss with a relative proportion of NK cells, indicating that the local factors seem to downregulate the final outcome of the cytotoxic immune response of NK cells [33]. Indeed, reduced expression of natural cytotoxicity receptor, NKG2D ligand UL16 binding protein 1 and Inter-Cellular Adhesion Molecule 1 has been seen on tumor cells $[37,38]$, which may specifically prevent NK cell activation.

Non-classical HLA-G in inhibition of both $C D 8^{+}$CTLs and NK cells

HLA-G is a non-classical class I antigen, originally detected in trophoblastic cells [39], where it is proposed to suppress maternal immune response against the semi-allogeneic fetus. It binds to the inhibitory receptors Ig-like transcript (ILT) 2, ILT4 or KIR2DL4, resulting in suppression of cytotoxicity of both $\mathrm{CD} 8^{+} \mathrm{CTL}$ and NK cells $[40,41]$. The protective role of HLA-G in 
carcinoma survival under immune surveillance is demonstrated in many studies with patients; in contrast to its null expression in normal epithelial cells and benign adenomas, a high percentage (30-90\%) of carcinoma cells expresses HLA-G in a variety of cancerous lesions, and its levels have been found to be significantly associated with clinicopathological features and shorter survival time of patients [42-45]. All these data indicate that carcinoma-expressing HLA-G could be one of important mechanisms for inhibition of both $\mathrm{CD} 8^{+} \mathrm{CTL}$ and NK cell mediated anti-carcinoma immunity.

\section{Induction of TIC apoptosis by expression of pro-apoptotic ligands \\ Fas ligand (FasL)}

FasL binding to death receptor Fas triggers apoptosis of Fas-expressing cells including TICs. Two patterns of FasL expression on carcinoma cells have been shown by immunohistochemical staining: (1) up-regulation of FasL expression on carcinoma is positively associated with clinicopathological features in patients, shown by that FasL expression is an early event in epithelial cell transformation (adenoma), followed by an increase in the percentage of FasL-expressing carcinoma cells in high-stage or -grade lesions, and the poorer survival of patients with high levels of FasL expression (Table 2); and (2) high levels of FasL expression have been seen as an independent factor for clinicopathological features, indicated by the positive staining of persistent FasL expression regardless of tumor stage, histologic grade, invasion and metastasis in many studies [47,58-61]. All of these observations suggest that FasL expression is critical for carcinoma survival by induction of TIC apoptosis. Indeed, the pro-apoptotic function of FasL on carcinoma cells has been demonstrated in both in vitro and in vivo; in co-cultures with a variety of carcinoma cell lines, FasL expressed on carcinoma cells induce apoptosis of lymphocytes in Fas-dependent manner [49,51,62-66], and in carcinoma biopsies from patients, the present of FasL on carcinoma cells is in parallel with apoptosis of TICs [53,60,67-69] or reduced number of TICs [70,71]. In the experimental studies with animal models, downregulation of FasL expression in carcinoma significantly reduces tumor development in syngeneic immunocompetent mice [72], while persistent expression of Fas enhances tumor growth along with an increase in lymphocyte apoptosis $[73,74]$, and is acquired for survival from active specific immunotherapy [75].

\section{Receptor-binding cancer antigen expressed on SiSo cells (RCAS) 1}

RCAS1 is a recently characterized human tumorassociated antigen expressed in a wide variety of cancer tissues, and induces cell cycle arrest and/or apoptosis in RCAS1 receptor-expressing immune cells. Like FasL on carcinoma cells, RCAS1 is expressed in a high percentage of carcinoma cells (30-100\%) and is significantly correlated with clinicopathological features including a shorter survival time for patients, and with apoptosis or reduction of TICs [76-81]. In co-cultures of interleukin (IL)-2 activated peripheral blood lymphocytes with human oral squamous cell carcinomas cell line (KB cells), lymphocyte apoptosis is associated with the presence of soluble RCAS1 in the medium [77]. In addition,

Table 2 FasL expression in carcinoma cancers

\begin{tabular}{|c|c|c|}
\hline Carcinoma type & Distribution of high FasL expression & References \\
\hline \multirow[t]{4}{*}{ Colorectal } & $19 \%$ in adenomas, $40 \%$ of stage $\mid-I I, 67 \%$ of stage III and $70 \%$ of stage IV of carcinoma & {$[46]$} \\
\hline & $40.9 \%$ in adenoma versus $80.8 \%$ in carcinoma & {$[47]$} \\
\hline & Higher incidence of metastases and poorer patients' survival associate with FasL positive carcinomas & {$[48]$} \\
\hline & 0 positive in normal epithelial cells, 2/7 positive in primary tumors, $4 / 4$ positive in hepatic metastatic tumors & [49] \\
\hline Adrenocortical & $37.7 \%$ in adenomas versus $100 \%$ in the carcinoma & {$[50]$} \\
\hline \multirow[t]{2}{*}{ Bladder transitional cell } & $\begin{array}{l}\text { 1) } 0 \% \text { in normal urothelium, } 0 \% \text { in } \mathrm{G} 1,14 \% \text { in } \mathrm{G} 2 \text {, and } 75 \% \text { in } \mathrm{G} 3 . \\
\text { 2) } 13 \% \text { in superficial Ta-T1 versus } 81 \% \text { in invasive } \mathrm{T} 2-\mathrm{T} 4\end{array}$ & {$[51]$} \\
\hline & $0 \%$ in normal urothelium, $19 \%$ in T1, 21\% in T2 and 49\% in T3 & {$[52]$} \\
\hline Pancreatic ductal & $\begin{array}{l}\text { 1) } 82 \% \text { in primary versus } 100 \% \text { in hepatic metastases } \\
\text { 2) Shorter survival for patients associates with FasL positive tumors }\end{array}$ & {$[53]$} \\
\hline Nasopharyngeal & $\begin{array}{l}\text { 1) } 0 \% \text { in stage } 1,57 \% \text { in stage } \|, 58 \% \text { in stage } I I \text { and } 82 \% \text { in stage } I V \text {; } \\
\text { 2) A lower rate of disease-free and overall survival for patients associates with positive FasL expression. }\end{array}$ & {$[54]$} \\
\hline Gastric & $36.2 \%$ in adenomas, $68.8 \%$ in early carcinoma, and 70.4\% in advanced carcinoma & {$[55]$} \\
\hline Cervical & $\begin{array}{l}\text { 1) } 5 / 14 \text { in inner } 2 / 3 \text { stromal invasion versus } 10 / 10 \text { outer } 2 / 3 \text { stromal invasion; } \\
\text { 2) } 7 / 15 \text { without LN metastasis versus } 8 / 9 \text { with } L N \text { metastasis; } \\
\text { 3) Reduced survival times in patients with FasL-expressing tumors }\end{array}$ & {$[56]$} \\
\hline Esophageal & $\begin{array}{l}\text { 1) Higher incidence of LN metastasis associates with the tumors containing }>25 \% \text { FasL expression; } \\
\text { 2) All cancer metastases in LN express FasL in }>50 \% \text { of the cells }\end{array}$ & {$[57]$} \\
\hline
\end{tabular}


similar to FasL and RCAS1, CD70 overexpressed on RCC promotes lymphocyte apoptosis by binding to its receptor $\mathrm{CD} 27$, indicating a proapoptotic role of $\mathrm{CD} 70$ in the elimination of TICs as well [82]. All these observations suggest that the direct induction of TIC apoptosis by persistent expression of FasL, RCAS1 or perhaps other apoptosis-inducing ligands (e.g. CD70) on carcinoma cells plays a role in the ability of carcinoma cells to escape from the anti-carcinoma immunity.

\section{Suppression of TIC activity by molecular and cellular factors}

\section{Immunoregulatory cytokine/cytokine-like: Transforming} growth factor (TGF)- $\beta 1$ and Galectin-1 (Gal-1)

TGF- $\beta 1$ is a multifunctional cytokine involved in immunosuppression. Numerous clinical studies have demonstrated that a higher level of TGF- $\beta 1$ expression is significantly associated with an invasive phenotype of tumors or metastases in patients [83-86]. In vitro a significant amount of TGF- $\beta 1$ is produced in the poorly differentiated prostate carcinoma cell lines but not in well-differentiated cells [87]. These data imply that TGF- $\beta 1$ may increase metastasis by a paracrine matter, such as suppression of local immune response or increased angiogenesis. Indeed, in the biopsies of cervical carcinoma tumors, an inverse relationship between TGF- $\beta 1$ expression in tumor cells and the extent of TICs is demonstrated [88]. This clinical observation is further confirmed by several experimental studies. In a mouse skin explant model, TGF- $\beta 1$ is produced by progressor types but not regressor squamous cell carcinoma lines, and this tumor-derived cytokine inhibits migration of professional APCs, Langerhans cells (LCs), and keeps them in an immature form [89], or transgenic expression of TGF- $\beta 1$ enhances growth of regressor squamous carcinoma cells in vitro and in vivo just like progressor phenotype, and reduces the number of infiltrating LCs, $\mathrm{CD}^{+}$and $\mathrm{CD} 8^{+} \mathrm{T}$ cells [90]. A further study with invasive colon carcinoma U9A cell line shows that decreasing TGF- $\beta 1$ expression by antisense reduces the invasive activity and metastasis of tumor cells to the liver [91]. All these studies suggest that carcinoma-derived TGF- $\beta$ plays an important role in the tumor metastasis, which may be caused by its immune suppressive function.

Gal-1 is a member of $\beta$-galacosidess binding protein family (galectins), and is a recently identified immunoregulatory cytokine-like molecule in cancer [92]. It has been documented that Gal-1 exhibits immunoregulatory effects by which it controls immune cell trafficking, regulates activation of dendritic cells (DCs) and induces T-cell apoptosis [93]. Up-regulation of Gal-1 expression has been seen in a variety of carcinoma biopsies, particularly in tumor-associated stroma, and is associated with tumor invasiveness or worse prognoses [94-97] and with reduced infiltrating $\mathrm{T}$ cells [98], suggesting that Gal-1, produced by carcinoma and/or stromal cells surrounding the tumor, may take a part in the carcinoma immune-escape by regulation of $\mathrm{T}$ cell homeostasis. This hypothesis is supported by a recent study showing that tumor cell-expressing Gal-1 induces T cell apoptosis in a co-culture system [99].

Immune inhibitory ligands: $B 7$ family members $(B 7-H 1,-H 3$ and $-\mathrm{H} 4)$

B7-H1 (PD-L1) is a ligand for the receptor PD-1 on $\mathrm{T}$ cell, and is known to negatively regulate $\mathrm{T}$-cell activation [100]. Similar to B7-H1, B7-H3 or -H4 ligation of $\mathrm{T}$ cells has a profound inhibitory effect on Th1 differentiation [101], as well as the proliferation, differentiation and cytotoxicity of $\mathrm{T}$ cells [102]. Over-expression of these B7 family members $(\mathrm{B} 7-\mathrm{H} 1,-\mathrm{H} 3$ or $-\mathrm{H} 4)$ has been documented in various types of carcinoma as compared to healthy controls: (1) H7-H1 in pancreatic tumors $[103,104]$, RCC $[105,106]$, human hepatocellular carcinoma (HCC) $[107,108]$, urothelial cell carcinoma (UCC) [109] and NSCLC [110]; (2) B7-H3 in UCC [111]; and (4) H7-H4 in NSCLC [112], breast cancer [113,114] and ovarian cancer [115]. Tumor B7-H1 expression is significantly associated with less TICs including PD-1 positive immune cells, poor tumor differentiation, advanced tumor stage and poorer survival of patients [103,104,106-110,115]. Similar correlation of B7-H4 with clinicopathological features has been reported as well [111-114].

In parallel with up-regulation of $\mathrm{B} 7-\mathrm{H} 1$, the number of PD- $1^{+} \mathrm{CD}^{+}$cells increases in tumor tissues, such as HCC $[108,116]$ and prostate cancer [117], and these tumorinfiltrating $\mathrm{CD}^{+}$cells have been shown to be impaired in the granule and cytokine productions [108,117-119]. In addition, blocking the interaction of $\mathrm{B} 7-\mathrm{H} 1$ with PD-1 using neutralizing antibody restores the effector function of tumor-infiltrating $\mathrm{T}$ cells $[108,119]$ and in a mouse model of pancreatic cancer, the antibody therapy, combined with gemocitabine, induces a complete regression of tumor growth [104]. All these studies indicate that up-regulation of B7 inhibitory molecules acts as an immunosuppressive strategy for carcinoma to escape from anticarcinoma immunity during cell-cell contact with $\mathrm{T}$ cells.

Depletion of amino acids enzymes: indoleamine 2,3dioxygenase (IDO) and arginase (ARG)

The mechanisms by which IDO induces immunosuppression have been recently reviewed [120]. IDO is a tryptophan-catabolising enzyme. Up-regulation of its synthesis has been documented in IFN- $\gamma$-stimulated cultures of KB oral carcinoma and WiDr colon adenocarcinoma [121], pancreatic carcinomal cells [122], hepatocellular carcinoma cell lines [123], and colorectal carcinoma cell lines [124]. Over-expression of IDO protein is reported in the cancerous lesions, and significantly correlates with 
carcinoma metastasis and poor prognosis in patients with a variety of carcinoma cancers [122-126]. The upregulation of IDO is associated with a significant reduction of $\mathrm{CD}^{+}$TICs [124], or with an increased number of regulatory $\mathrm{T}$ (Treg) cells in the metastatic carcinoma in lymph nodes (LNs) [122]. Ectopic expression of IDO enhances tumor growth of the human endometrial carcinoma cell line AMEC and suppresses cytotoxicity of NK cells in a mouse xenograft model [127]. All these observations suggest that IDO-high expression in carcinoma cells in primary tumors may defeat the invasion of effector $\mathrm{T}$ cells and NK cells via local tryptophan depletion as well as production of proapoptotic tryptophan catabolites. Also, IDO in metastatic carcinoma cells may enhance the differentiation of Treg cells as a potent immunosuppressive strategy.

ARG is an arginine-metabolic enzyme converting L-arginine into L-ornithine and urea [128]. It has been suggested that arginine is one of essential amino acids for $T$ cell activation and proliferation [129], and the depletion of extracellular arginine by ARG results in the modulation of $\mathrm{CD} 3 \zeta$ chain expression and proliferative suppression in T cells [130]. A significantly high level of ARG activity has been demonstrated in the carcinomas of the prostate [131], the gallbladder [132] and the lung $[133,134]$, but the evidence for the contribution of ARG activity to tumor immune escape is still weak; ARGII and NOSII together has been shown to participate in local peroxynitrite dependent immune suppression of prostate cancer [135], but not seen in lung cancer [136]. However, this enzyme may play a critical role in the immunosuppressive activity of tumor-induced myeloidderived suppressor cells (MDSCs) as discussed below.

Immunosuppressive cells: $\mathrm{CD} 4^{+} \mathrm{CD} 25^{+} \mathrm{Foxp}^{+}$regulatory $T$ (Treg) cells and Tumor-induced myeloid-derived suppressor cells (MDSCs)

Treg cells can inactivate both effector/helper $\mathrm{T}$ and $\mathrm{B}$ cells. After activation, Treg cells not only produce abundant anti-inflammatory cytokine IL-10 and TGF- $\beta$, but also express cell surface CTLA-4, which binds to B7 molecules on APCs, resulting in suppression of effector $\mathrm{T}$ cells and their dependent $\mathrm{B}$ cells. Numerous studies with cancer patients have demonstrated that the prevalence of Treg cells is significantly high in cancerous lesions as compared to those in healthy controls [136-141], and the percentage of Treg cells among TICs positively correlates with a significantly lower survival rate $[138,139,142]$. In mice challenged with pancreas adenocarcinoma cells (Pan02), depletion of Treg cells promotes a tumor-specific immune response, and significantly associates with smaller size of tumor and longer survival [143]. All these studies suggest that an increase in Treg cells in TICs may play a central role in selftolerance to carcinoma cells, which may "hijack" these
Treg cells as an effective strategy for immunoescape by suppression of anti-carcinoma immunity.

However, the mechanism of elevation of Treg cells in TICs is not fully clarified, but may be due to their local proliferation/differentiation or recruitment from circulation to cancerous lesion or to both. Indeed, the presence of Treg cells in carcinoma lesions is in conjunction with immature DCs, Th2 cytokine dominant microenvironment, prostaglandin E2 (PGE2) and IDO activity $[122,144,145]$ or is required the function of CCL22 [146] and/or CCL5 [147]. Chemokine CCL22 and CCL5 mediate trafficking of Treg cells to the tumors, whereas immature DCs, Th2 cytokines and PGE2 favor Treg cell proliferation and/or differentiation.

MDSCs represent a heterogeneous population of immunosuppressive cells expressing a variety of surface markers, such as CD11c ${ }^{+}, \mathrm{CD}_{11 \mathrm{~b}^{+}}, \mathrm{CD}_{3}{ }^{+}, \mathrm{CD} 34^{+}$and $\mathrm{CD}_{15}{ }^{+}$. In patients with all different types of carcinomas, an increasing number of MDSCs have been found in peripheral blood [148-150] and/or intratumor lesions [151-153]. The frequency of these cells also positively correlates with the incidence of recurrence or metastatic disease in patients $[153,154]$. Experimental studies show that MDSCs can function as potent suppressors of cytotoxicity of both effector $\mathrm{CD}^{+} \mathrm{T}$-cells [155] and NK cells [156]. The immunosuppressive activities of MDSCs may depend on the activity of ARG and/or reactive oxygen species they produce $[150,157,158]$ or the induction of Foxp3 ${ }^{+}$Treg cells [159]. All these studies suggest that MDSCs may be one of important factors responsible not only for systemic immune dysfunction in cancer patients but also for local carcinoma immune escape.

\section{Conclusions}

The evidence from the limited literature we reviewed clearly indicates that carcinoma development in patients closely correlates to its ability to inactivate effector cytotoxic lymphocytes (i.e. CD8 ${ }^{+} \mathrm{CTL}$ and NK cells), to induce TIC apoptosis and/or to suppress the anti-carcinoma immune response, as indicated by: (1) down-regulation of antigen-presenting protein HLA class I; (2) up-regulation of immunosuppressive proteins, such as cell surface FasL, HLA-G, immune inhibitory ligand B7 family members, secreted cytokine TGF- $\beta$ and Gal-1, enzyme IDO and perhaps ARG, and (3) induction/expansion of immunosuppressive cells: MDSCs and/or Foxp $3^{+}$Treg cells (Figure 1). Thus, it must be acknowledged that carcinoma develops multiple adaptation mechanisms against immune surveillance, but different types of carcinoma cancer may use different anti-immune strategies depending on the spectrum of host anti-carcinoma immunity in patients. Further understanding of these mechanisms by which 


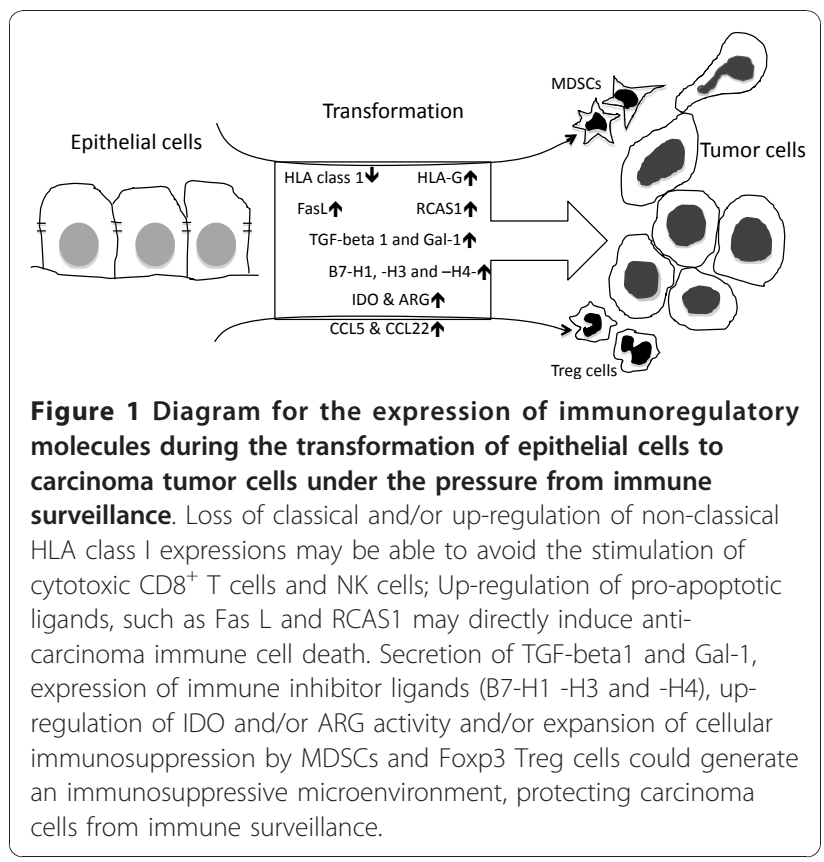

carcinomas cells resist to anti-carcinoma immunity will lead to develop more effective immunotherapyi

\section{Abbreviations}

APC: Antigen presenting cell; ARG: Arginase; CTL: Cytotoxic T lymphocyte; DC: Dendritic cell; Gal: Galectin; HCC: human hepatocellular carcinoma; HLA: Human leukocyte antigen; HNSCC: Head and neck squamous cell carcinoma; IDO: Indoleamine 2,3-dioxygenase; IL: Interleukin; ILT: Ig-like transcript; KIR: Killer cell immunoglobulin-like receptor; LC: Langerhans cell; MDSC: Tumorinduced myeloid-derived suppressor cell; NK: Natural killer; NSCLC: Non-small cell lung cancer; PGE2: Prostaglandin E2; RCAS1: Receptor-binding cancer antigen expressed on SiSo cells; RCC: Renal cell carcinomas; TGF: Transforming growth factor; TIC: Tumor-infiltrating immune cell; Treg: Regulatory T cel; UCC: Urothelial cell carcinoma.

\section{Acknowledgements}

The authors would like to thank Dr. Michael E. Cox (Vancouver Prostate Centre, BC) for constructive comments, and want to apologize to those authors important contributions to this field are not mentioned in this review because of the length limitation.

Funding

This work was supported by the start-up funding from the University of British Columbia and the Vancouver Coast Health Research Institute (C.D.) and a grant from the Canadian Institutes of Health Research (Y.Z.).

\section{Author details}

'Department of Urologic Sciences, University of British Columbia, Vancouver, BC V5Z 1M9, Canada. Immunity and Infection Research Centre, Vancouver Coastal Health Research Institute, Vancouver, BC V6H 3Z6, Canada. ${ }^{3}$ Vancouver Prostate Centre, Vancouver, BC V6H 3Z6, Canada. ${ }^{4}$ Living Tumor Laboratory, BC Cancer Agency, Vancouver, BC V5Z 1L3, Canada.

\section{Authors' contributions}

YW initiated the concept. CD drafted the manuscript. Both authors participated in writing, read and approved the final manuscript.

\section{Competing interests}

The authors declare that they have no competing interests.
Received: 15 November 2010 Accepted: 21 January 2011

Published: 21 January 2011

\section{References}

1. Cole WH: Relationship of causative factors in spontaneous regression of cancer to immunologic factors possibly effective in cancer. J Surg Oncol 1976, 8:391-411.

2. Whiteside $\mathrm{TL}$ : The role of immune cells in the tumor microenvironment. Cancer Treat Res 2006, 130:103-124.

3. Maccalli C, Scaramuzza S, Parmiani G: TNK cells (NKG2D+ $\mathrm{CD}^{+}$or $\mathrm{CD}^{+} \mathrm{T}$ lymphocytes) in the control of human tumors. Cancer Immunol Immunother 2009, 58:801-808.

4. Nelson $\mathrm{BH}: \mathrm{CD}_{2} \mathrm{O}^{+} \mathrm{B}$ cells: the other tumor-infiltrating lymphocytes. J Immunol 2010, 185:4977-4982.

5. Cho Y, Miyamoto M, Kato K, Fukunaga A, Shichinohe T, Kawarada Y, Hida Y, Oshikiri T, Kurokawa T, Suzuoki M, Nakakubo Y, Hiraoka K, Murakami S, Shinohara T, Itoh T, Okushiba S, Kondo S, Katoh $\mathrm{H}_{\mathrm{CD}} \mathrm{CD}^{+}$and $\mathrm{CD} 8^{+} \mathrm{T}$ cells cooperate to improve prognosis of patients with esophageal squamous cell carcinoma. Cancer Res 2003, 63:1555-1559.

6. Eerola AK, Soini Y, Paakko P: Tumour infiltrating lymphocytes in relation to tumour angiogenesis, apoptosis and prognosis in patients with large cell lung carcinoma. Lung Cancer 1999, 26:73-83.

7. Oberg A, Samii S, Stenling R, Lindmark G: Different occurrence of $C D 8^{+}$, $\mathrm{CD} 45 \mathrm{RO}^{+}$, and $\mathrm{CD} 8^{+}$immune cells in regional lymph node metastases from colorectal cancer as potential prognostic predictors. Int I Colorectal Dis 2002, 17:25-29.

8. Chikamatsu K, Eura M, Nakano K, Masuyama K, Ishikawa T: Functional and T cell receptor gene usage analysis of cytotoxic $T$ lymphocytes in fresh tumor-infiltrating lymphocytes from human head and neck cancer. Jpn J Cancer Res 1995, 86:477-483.

9. Housseau F, Zeliszewski D, Roy M, Paradis V, Richon S, Ricour A, Bougaran J, Prapotnich D, Vallancien G, Benoit G, Desportes L, Bedossa P, Hercend T, Bidart JM, Bellet D: MHC-dependent cytolysis of autologous tumor cells by lymphocytes infiltrating urothelial carcinomas. Int J Cancer 1997, 71:585-594.

10. Verdegaal EM, Hoogstraten C, Sandel MH, Kuppen PJ, Brink AA, Claas FH, Gorsira MC, Graadt van Roggen JF, Osanto S: Functional CD8+ T cells infiltrate into nonsmall cell lung carcinoma. Cancer Immunol Immunother 2007, 56:587-600.

11. Di Modugno F, Bronzi G, Scanlan MJ, Del Bello D, Cascioli S, Venturo I, Botti C, Nicotra MR, Mottolese M, Natali PG, Santoni A, Jager E, Nistico P: Human Mena protein, a serex-defined antigen overexpressed in breast cancer eliciting both humoral and $\mathrm{CD} 8^{+} \mathrm{T}$-cell immune response. Int $J$ Cancer 2004, 109:909-918.

12. Mosolits S, Steinitz M, Harmenberg U, Ruden U, Eriksson E, Mellstedt $H$, Fagerberg J: Immunogenic regions of the GA733-2 tumour-associated antigen recognised by autoantibodies of patients with colorectal carcinoma. Cancer Immunol Immunother 2002, 51:209-218.

13. Zeng G, Aldridge ME, Wang Y, Pantuck AJ, Wang AY, Liu YX, Han Y, Yuan YH, Robbins PF, Dubinett SM, deKernion JB, Belldegrun AS: Dominant B cell epitope from NY-ESO-1 recognized by sera from a wide spectrum of cancer patients: implications as a potential biomarker. Int $J$ Cancer 2005, 114:268-273.

14. Kerr KM, Johnson SK, King G, Kennedy MM, Weir J, Jeffrey R: Partial regression in primary carcinoma of the lung: does it occur? Histopathology 1998, 33:55-63.

15. Patel A, Halliday GM, Barnetson RS: $\mathrm{CD}^{+} \mathrm{T}$ lymphocyte infiltration correlates with regression of a UV-induced squamous cell carcinoma. J Dermatol Sci 1995, 9:12-19.

16. Patel A, Halliday GM, Cooke BE, Barnetson RS: Evidence that regression in keratoacanthoma is immunologically mediated: a comparison with squamous cell carcinoma. Br J Dermatol 1994, 131:789-798.

17. Nedergaard BS, Ladekarl M, Thomsen HF, Nyengaard JR, Nielsen K: Low density of $\mathrm{CD}^{+}, \mathrm{CD}^{+}$and $\mathrm{CD}^{+}$cells is associated with increased risk of relapse in squamous cell cervical cancer. Br J Cancer 2007, 97:1135-1138.

18. Øvestad IT, Gudlaugsson E, Skaland I, Malpica A, Kruse AJ, Janssen EA, Baak JP: Local immune response in the microenvironment of CIN2-3 with and without spontaneous regression. Mod Pathol 2010, 23:1231-1240.

19. Wroblewski JM, Bixby DL, Borowski C, Yannelli JR: Characterization of human non-small cell lung cancer (NSCLC) cell lines for expression of 
MHC, co-stimulatory molecules and tumor-associated antigens. Lung Cancer 2001, 33:181-194.

20. Cabrera T, Pedrajas G, Cozar JM, Garrido A, Vicente J, Tallada M, Garrido F: HLA class I expression in bladder carcinomas. Tissue Antigens 2003, 62:324-327.

21. Levin I, Klein T, Goldstein J, Kuperman O, Kanetti J, Klein B: Expression of class I histocompatibility antigens in transitional cell carcinoma of the urinary bladder in relation to survival. Cancer 1991, 68:2591-2594.

22. Klein B, Klein T, Nyska A, Shapira J, Figer A, Schwartz A, Rakovsky E, Livni E, Lurie H: Expression of HLA class I and class II in gastric carcinoma in relation to pathologic stage. Tumour Biol 1991, 12:68-74

23. Rockett JC, Darnton SJ, Crocker J, Matthews HR, Morris AG: Expression of HLA-ABC, HLA-DR and intercellular adhesion molecule-1 in oesophageal carcinoma. J Clin Pathol 1995, 48:539-544.

24. Redondo M, Concha A, Oldiviela R, Cueto A, Gonzalez A, Garrido F, Ruiz Cabello F: Expression of HLA class I and II antigens in bronchogenic carcinomas: its relationship to cellular DNA content and clinicalpathological parameters. Cancer Res 1991, 51:4948-4954

25. Passlick B, Pantel K, Kubuschok B, Angstwurm M, Neher A, Thetter O, Schweiberer L, Izbicki JR: Expression of MHC molecules and ICAM-1 on non-small cell lung carcinomas: association with early lymphatic spread of tumour cells. Eur J Cancer 1996, 32A:141-145.

26. Vitale M, Rezzani R, Rodella L, Zauli G, Grigolato P, Cadei M, Hicklin DJ, Ferrone S: HLA class I antigen and transporter associated with antigen processing (TAP1 and TAP2) down-regulation in high-grade primary breast carcinoma lesions. Cancer Res 1998, 58:737-742.

27. Saio $M$, Teicher $M$, Campbell $G$, Feiner $H$, Delgado $Y$, Frey AB: Immunocytochemical demonstration of down regulation of HLA class-I molecule expression in human metastatic breast carcinoma. Clin Exp Metastasis 2004, 21:243-249.

28. Ryschich E, Notzel T, Hinz U, Autschbach F, Ferguson J, Simon I, Weitz J, Frohlich B, Klar E, Buchler MW, Schmidt J: Control of T-cell-mediated immune response by HLA class I in human pancreatic carcinoma. Clin Cancer Res 2005, 11(2 Pt 1):498-504.

29. Sharpe JC, Abel PD, Gilbertson JA, Brawn P, Foster CS: Modulated expression of human leucocyte antigen class I and class II determinants in hyperplastic and malignant human prostatic epithelium. $\mathrm{Br} J$ Urol 1994, 74:609-616.

30. Brasanac D, Markovic-Lipkovski J, Hadzi-Djokic J, Muller GA, Muller CA: Immunohistochemical analysis of HLA class II antigens and tumor infiltrating mononuclear cells in renal cell carcinoma: correlation with clinical and histopathological data. Neoplasma 1999, 46:173-178.

31. Hilders CG, Houbiers JG, van Ravenswaay Claasen HH, Veldhuizen RW, Fleuren GJ: Association between HLA-expression and infiltration of immune cells in cervical carcinoma. Lab Invest 1993, 69:651-659.

32. Hilders CG, Munoz IM, Nooyen Y, Fleuren GJ: Altered HLA expression by metastatic cervical carcinoma cells as a factor in impaired immune surveillance. Gynecol Oncol 1995, 57:366-375.

33. Cruz I, Meijer CJ, Walboomers JM, Snijders PJ, Van der Waal I: Lack of MHC class I surface expression on neoplastic cells and poor activation of the secretory pathway of cytotoxic cells in oral squamous cell carcinomas. $\mathrm{Br}$ J Cancer 1999, 81:881-889.

34. Grandis JR, Falkner DM, Melhem MF, Gooding WE, Drenning SD, Morel PA: Human leukocyte antigen class I allelic and haplotype loss in squamous cell carcinoma of the head and neck: clinical and immunogenetic consequences. Clin Cancer Res 2000, 6:2794-2802.

35. Gati A, Da Rocha S, Guerra N, Escudier B, Moretta A, Chouaib S, Angevin E, Caignard A: Analysis of the natural killer mediated immune response in metastatic renal cell carcinoma patients. Int J Cancer 2004, 109:393-401.

36. Lanier LL: Natural killer cells: from no receptors to too many. Immunity 1997, 6:371-378

37. Doubrovina ES, Doubrovin MM, Vider E, Sisson RB, O'Reilly RJ, Dupont B, Vyas YM: Evasion from NK cell immunity by MHC class I chain-related molecules expressing colon adenocarcinoma. J Immunol 2003, 171:6891-6899.

38. Le Maux Chansac B, Moretta A, Vergnon I, Opolon P, Lecluse Y, Grunenwald D, Kubin M, Soria JC, Chouaib S, Mami-Chouaib F: NK cells infiltrating a MHC class I-deficient lung adenocarcinoma display impaired cytotoxic activity toward autologous tumor cells associated with altered NK cell-triggering receptors. J Immunol 2005, 175:5790-5798.
39. Kovats S, Main EK, Librach C, Stubblebine M, Fisher SJ, DeMars R: A class I antigen, HLA-G, expressed in human trophoblasts. Science 1990 248:220-223.

40. Le Gal FA, Riteau B, Sedlik C, Khalil-Daher I, Menier C, Dausset J, Guillet JG, Carosella ED, Rouas-Freiss N: HLA-G-mediated inhibition of antigenspecific cytotoxic T lymphocytes. Int Immunol 1999, 11:1351-1356.

41. Rajagopalan S, Long EO: A human histocompatibility leukocyte antigen (HLA)-G-specific receptor expressed on all natural killer cells. J Exp Med 1999, 189:1093-1100

42. Barrier BF, Kendall BS, Sharpe-Timms KL, Kost ER: Characterization of human leukocyte antigen-G (HLA-G) expression in endometrial adenocarcinoma. Gynecol Oncol 2006, 103:25-30.

43. Ibrahim EC, Guerra N, Lacombe MJ, Angevin E, Chouaib S, Carosella ED, Caignard A, Paul P: Tumor-specific up-regulation of the nonclassical class I HLA-G antigen expression in renal carcinoma. Cancer Res 2001, 61:6838-6845.

44. Lefebvre S, Antoine M, Uzan S, McMaster M, Dausset J, Carosella ED, Paul P: Specific activation of the non-classical class I histocompatibility HLA-G antigen and expression of the ILT2 inhibitory receptor in human breast cancer. J Pathol 2002, 196:266-274.

45. Ye SR, Yang H, Li K, Dong DD, Lin XM, Yie SM: Human leukocyte antigen $\mathrm{G}$ expression: as a significant prognostic indicator for patients with colorectal cancer. Mod Pathol 2007, 20:375-383.

46. Belluco C, Esposito G, Bertorelle R, Alaggio R, Giacomelli L, Bianchi LC, Nitti $D$, Lise M: Fas ligand is up-regulated during the colorectal adenoma-carcinoma sequence. Eur J Surg Oncol 2002, 28:120-125.

47. Shimoyama M, Kanda T, Liu L, Koyama Y, Suda T, Sakai Y, Hatakeyama K Expression of Fas ligand is an early event in colorectal carcinogenesis. J Surg Oncol 2001, 76:63-68.

48. Nozoe T, Yasuda M, Honda M, Inutsuka S, Korenaga D: Fas ligand expression is correlated with metastasis in colorectal carcinoma. Oncology 2003, 65:83-88.

49. Shiraki K, Tsuji N, Shioda T, Isselbacher K, Takahashi H: Expression of Fas ligand in liver metastases of human colonic adenocarcinomas. Proc Natl Acad Sci USA 1997, 94:6420-6425.

50. Wolkersdorfer GW, Marx C, Brown J, Schroder S, Fussel M, Rieber EP Kuhlisch E, Ehninger G, Bornstein SR: Prevalence of HLA-DRB1 genotype and altered Fas/Fas ligand expression in adrenocortical carcinoma. J Clin Endocrinol Metab 2005, 90:1768-1774.

51. Chopin D, Barei-Moniri R, Maille P, Le Frere-Belda MA, Muscatelli-Groux B, Merendino N, Lecerf L, Stoppacciaro A, Velotti F: Human urinary bladder transitional cell carcinomas acquire the functional Fas ligand during tumor progression. Am J Pathol 2003, 162:1139-1149.

52. Korkolopoulou P, Goudopoulou A, Voutsinas G, Thomas-Tsagli E, Kapralos P, Patsouris E, Saetta AA: c-FLIP expression in bladder urothelial carcinomas: its role in resistance to Fas-mediated apoptosis and clinicopathologic correlations. Urology 2004, 63:1198-1204.

53. Ohta T, Elnemr A, Kitagawa H, Kayahara M, Takamura H, Fujimura T, Nishimura G, Shimizu K, Yi SQ, Miwa K: Fas ligand expression in human pancreatic cancer. Oncol Rep 2004, 12:749-754.

54. Ho SY, Guo HR, Chen HH, Hsiao JR, Jin YT, Tsai ST: Prognostic implications of Fas-ligand expression in nasopharyngeal carcinoma. Head Neck 2004, 26:977-983.

55. Osaki M, Kase S, Kodani I, Watanabe M, Adachi H, Ito H: Expression of Fas and Fas ligand in human gastric adenomas and intestinal-type carcinomas: correlation with proliferation and apoptosis. Gastric Cancer 2001, 4:198-205.

56. Kase H, Aoki Y, Tanaka K: Fas ligand expression in cervical adenocarcinoma: relevance to lymph node metastasis and tumor progression. Gynecol Oncol 2003, 90:70-74.

57. Younes M, Schwartz MR, Ertan A, Finnie D, Younes A: Fas ligand expression in esophageal carcinomas and their lymph node metastases. Cancer 2000, 88:524-528.

58. Bennett MW, O'Connell J, O'Sullivan GC, Roche D, Brady C, Kelly J, Collins JK, Shanahan F: Expression of Fas ligand by human gastric adenocarcinomas: a potential mechanism of immune escape in stomach cancer. Gut 1999, 44:156-162.

59. Bernstorff WV, Glickman JN, Odze RD, Farraye FA, Joo HG Goedegebuure PS, Eberlein TJ: Fas (CD95/APO-1) and Fas ligand expression in normal pancreas and pancreatic tumors. Implications for immune privilege and immune escape. Cancer 2002, 94:2552-2560. 
60. Ibrahim R, Frederickson H, Parr A, Ward Y, Moncur J, Khleif SN: Expression of FasL in squamous cell carcinomas of the cervix and cervical intraepithelial neoplasia and its role in tumor escape mechanism. Cancer 2006, 106:1065-1077.

61. O'Connell J, Bennett MW, O'Sullivan GC, Roche D, Kelly J, Collins JK, Shanahan F: Fas ligand expression in primary colon adenocarcinomas: evidence that the Fas counterattack is a prevalent mechanism of immune evasion in human colon cancer. J Pathol 1998, 186:240-246.

62. Gastman BR, Atarshi $Y$, Reichert TE, Saito T, Balkir L, Rabinowich H, Whiteside TL: Fas ligand is expressed on human squamous cell carcinomas of the head and neck, and it promotes apoptosis of $\mathrm{T}$ lymphocytes. Cancer Res 1999, 59:5356-5364.

63. Niehans GA, Brunner T, Frizelle SP, Liston JC, Salerno CT, Knapp DJ, Green DR, Kratzke RA: Human lung carcinomas express Fas ligand. Cancer Res 1997, 57:1007-1012.

64. Perabo FG, Kamp S, Schmidt D, Lindner H, Steiner G, Mattes RH, Wirger A, Pegelow K, Albers P, Kohn EC, von Ruecker A, Mueller SC: Bladder cancer cells acquire competent mechanisms to escape Fas-mediated apoptosis and immune surveillance in the course of malignant transformation. $\mathrm{Br} J$ Cancer 2001, 84:1330-1338.

65. Strand S, Hofmann WJ, Hug H, Muller M, Otto G, Strand D, Mariani SM, Stremmel W, Krammer PH, Galle PR: Lymphocyte apoptosis induced by CD95 (APO-1/Fas) ligand-expressing tumor cells-a mechanism of immune evasion? Nat Med 1996, 2:1361-1366.

66. Ungefroren $H$, Voss $M$, Jansen $M$, Roeder C, Henne-Bruns D, Kremer B, Kalthoff $\mathrm{H}$ : Human pancreatic adenocarcinomas express Fas and Fas ligand yet are resistant to Fas-mediated apoptosis. Cancer Res 1998, 58:1741-1749.

67. Nagashima H, Mori M, Sadanaga N, Mashino K, Yoshikawa Y, Sugimachi K: Expression of Fas ligand in gastric carcinoma relates to lymph node metastasis. Int J Oncol 2001, 18:1157-1162.

68. Okada K, Komuta K, Hashimoto S, Matsuzaki S, Kanematsu T, Koji T: Frequency of apoptosis of tumor-infiltrating lymphocytes induced by fas counterattack in human colorectal carcinoma and its correlation with prognosis. Clin Cancer Res 2000, 6:3560-3564.

69. Shimonishi T, Isse K, Shibata F, Aburatani I, Tsuneyama K, Sabit H, Harada K, Miyazaki K, Nakanuma Y: Up-regulation of fas ligand at early stages and down-regulation of Fas at progressed stages of intrahepatic cholangiocarcinoma reflect evasion from immune surveillance. Hepatology 2000, 32(4 Pt 1):761-769.

70. Bennett MW, O'Connell J, O'Sullivan GC, Brady C, Roche D, Collins JK, Shanahan F: The Fas counterattack in vivo: apoptotic depletion of tumorinfiltrating lymphocytes associated with Fas ligand expression by human esophageal carcinoma. J Immunol 1998, 160:5669-5675.

71. Houston A, Waldron-Lynch FD, Bennett MW, Roche D, O'Sullivan GC, Shanahan $\mathrm{F}, \mathrm{O}^{\prime} \mathrm{C}$ onnell J: Fas ligand expressed in colon cancer is not associated with increased apoptosis of tumor cells in vivo. Int J Cancer 2003, 107:209-214

72. Ryan AE, Shanahan F, O'Connell J, Houston AM: Addressing the "Fas counterattack" controversy: blocking fas ligand expression suppresses tumor immune evasion of colon cancer in vivo. Cancer Res 2005, 65:9817-9823.

73. Nishimatsu H, Takeuchi T, Ueki T, Kajiwara T, Moriyama N, Ishida T, Li B, Kakizoe T, Kitamura T: CD95 ligand expression enhances growth of murine renal cell carcinoma in vivo. Cancer Immunol Immunother 1999, 48:56-61.

74. Wada A, Tada Y, Kawamura K, Takiguchi Y, Tatsumi K, Kuriyama T, Takenouchi T, O-Wang J, Tagawa M: The effects of FasL on inflammation and tumor survival are dependent on its expression levels. Cancer Gene Ther 2007, 14:262-267.

75. Cefai D, Schwaninger R, Balli M, Brunner T, Gimmi CD: Functional characterization of Fas ligand on tumor cells escaping active specific immunotherapy. Cell Death Differ 2001, 8:687-695.

76. Dutsch-Wicherek M, Tomaszewska R, Lazar A, Wicherek L, Skladzien J: The association between RCAS1 expression in laryngeal and pharyngeal cancer and its healthy stroma with cancer relapse. BMC Cancer 2009, 9:35.

77. Fukuda M, Tanaka A, Hamao A, Suzuki S, Kusama K, Sakashita H: Expression of RCAS1 and its function in human squamous cell carcinoma of the oral cavity. Oncol Rep 2004, 12:259-267.
78. Giaginis C, Davides D, Zarros A, Noussia O, Zizi-Serbetzoglou A, Kouraklis G, Theocharis S: Clinical significance of tumor-associated antigen RCAS1 expression in human pancreatic ductal adenocarcinoma. Dig Dis Sci 2008, 53:1728-1734.

79. Kato H, Nakajima M, Masuda N, Faried A, Sohda M, Fukai Y, Miyazaki T, Fukuchi M, Tsukada K, Kuwano H: Expression of RCAS1 in esophageal squamous cell carcinoma is associated with a poor prognosis. I Surg Oncol 2005, 90:89-94.

80. Toyoshima T, Nakamura S, Kumamaru W, Kawamura E, Ishibashi $H_{\text {, }}$ Hayashida JN, Moriyama M, Ohyama Y, Sasaki M, Shirasuna K: Expression of tumor-associated antigen RCAS1 and its possible involvement in immune evasion in oral squamous cell carcinoma. J Oral Pathol Med 2006, 35:361-368.

81. Tsujitani S, Saito H, Oka S, Sakamoto T, Kanaji S, Tatebe S, Ikeguchi M: Prognostic significance of RCAS1 expression in relation to the infiltration of dendritic cells and lymphocytes in patients with esophageal carcinoma. Dig Dis Sci 2007, 52:549-554.

82. Diegmann J, Junker K, Loncarevic IF, Michel S, Schimmel B, von Eggeling F: Immune escape for renal cell carcinoma: CD70 mediates apoptosis in lymphocytes. Neoplasia 2006, 8:933-938.

83. Friedman E, Gold LI, Klimstra D, Zeng ZS, Winawer S, Cohen A: High levels of transforming growth factor beta 1 correlate with disease progression in human colon cancer. Cancer Epidemiol Biomarkers Prev 1995, 4:549-554.

84. Mitropoulos D, Kiroudi A, Christelli E, Serafetinidis E, Zervas A, Anastasiou I, Dimopoulos C: Expression of transforming growth factor beta in renal cell carcinoma and matched non-involved renal tissue. Urol Res 2004, 32:317-322.

85. Santin AD, Hermonat PL, Hiserodt JC, Fruehauf J, Schranz V, Barclay D, Pecorelli S, Parham GP: Differential transforming growth factor-beta secretion in adenocarcinoma and squamous cell carcinoma of the uterine cervix. Gynecol Oncol 1997, 64:477-480.

86. Walker RA, Dearing SJ: Transforming growth factor beta 1 in ductal carcinoma in situ and invasive carcinomas of the breast. Eur $J$ Cancer 1992, 28:641-644.

87. Steiner MS, Zhou ZZ, Tonb DC, Barrack ER: Expression of transforming growth factor-beta 1 in prostate cancer. Endocrinology 1994, 135:2240-2247.

88. Hazelbag S, Gorter A, Kenter GG, van den Broek L, Fleuren G: Transforming growth factor-beta1 induces tumor stroma and reduces tumor infiltrate in cervical cancer. Hum Pathol 2002, 33:1193-1199.

89. Halliday GM, Le S: Transforming growth factor-beta produced by progressor tumors inhibits, while IL-10 produced by regressor tumors enhances, Langerhans cell migration from skin. Int Immunol 2001, 13:1147-1154.

90. Weber F, Byrne SN, Le S, Brown DA, Breit SN, Scolyer RA, Halliday GM: Transforming growth factor-beta1 immobilises dendritic cells within skin tumours and facilitates tumour escape from the immune system. Cancer Immunol Immunother 2005, 54:898-906.

91. Huang F, Newman E, Theodorescu D, Kerbel RS, Friedman E: Transforming growth factor beta 1 (TGF beta 1) is an autocrine positive regulator of colon carcinoma U9 cells in vivo as shown by transfection of a TGF beta 1 antisense expression plasmid. Cell Growth Differ 1995, 6:1635-1642.

92. Demydenko D, Berest I: Expression of galectin-1 in malignant tumors. Exp Oncol 2009, 31:74-79.

93. Cooper D, llarregui JM, Pesoa SA, Croci DO, Perretti M, Rabinovich GA: Multiple functional targets of the immunoregulatory activity of galectin1: Control of immune cell trafficking, dendritic cell physiology, and T-cell fate. Methods Enzymol 2010, 480:199-244.

94. Jung EJ, Moon HG, Cho BI, Jeong CY, Joo YT, Lee YJ, Hong SC, Choi SK, Ha WS, Kim JW, Lee CW, Lee JS, Park ST: Galectin-1 expression in cancerassociated stromal cells correlates tumor invasiveness and tumor progression in breast cancer. Int J Cancer 2007, 120:2331-2338.

95. Saussez S, Decaestecker C, Lorfevre F, Cucu DR, Mortuaire G, Chevalier D, Wacreniez A, Kaltner H, André S, Toubeau G, Camby I, Gabius HJ, Kiss R: High level of galectin-1 expression is a negative prognostic predictor of recurrence in laryngeal squamous cell carcinomas. Int J Oncol 2007, 30:1109-1117.

96. Spano D, Russo R, Di Maso V, Rosso N, Terracciano LM, Roncalli M, Tornillo L, Capasso M, Tiribelli C, Iolascon A: Galectin-1 and its involvement in hepatocellular carcinoma aggressiveness. Mol Med 2010, 16:102-115. 
97. Chiang WF, Liu SY, Fang LY, Lin CN, Wu MH, Chen YC, Chen YL, Jin YT: Overexpression of galectin-1 at the tumor invasion front is associated with poor prognosis in early-stage oral squamous cell carcinoma. Oral Oncol 2008, 44:325-334.

98. Le QT, Shi G, Cao H, Nelson DW, Wang Y, Chen EY, Zhao S, Kong C, Richardson D, O'Byrne KJ, Giaccia AJ, Koong AC: Galectin-1: a link between tumor hypoxia and tumor immune privilege. J Clin Oncol 2005, 23:8932-8941.

99. Kovács-Sólyom F, Blaskó A, Fajka-Boja R, Katona RL, Végh L, Novák J, Szebeni GJ, Krenács L, Uher F, Tubak V, Kiss R, Monostori E: Mechanism of tumor cell-induced T-cell apoptosis mediated by galectin-1. Immunol Lett 2010, 127:108-118.

100. Dong H, Zhu G, Tamada K, Chen L: B7-H1, a third member of the B7 family, co-stimulates T-cell proliferation and interleukin-10 secretion. Nat Med 1999, 5:1365-1369.

101. Suh WK, Gajewska BU, Okada H, Gronski MA, Bertram EM, Dawicki W, Duncan GS, Bukczynski J, Plyte S, Elia A, Wakeham A, Itie A, Chung S, Da Costa J, Arya S, Horan T, Campbell P, Gaida K, Ohashi PS, Watts TH, Yoshinaga SK, Bray MR, Jordana M, Mak TW: The B7 family member B7-H3 preferentially down-regulates $\mathrm{T}$ helper type 1-mediated immune responses. Nat Immunol 2003, 4:899-906.

102. Sica G, Zelano G, Settesoldi D, lacopino F: Regulation of prostate-specific antigen gene expression by an $\mathrm{LH}-\mathrm{RH}$ analogue in human prostatic cells. Anticancer Res 2003, 23:1283-1287.

103. Geng L, Huang D, Liu J, Qian Y, Deng J, Li D, Hu Z, Zhang J, Jiang G, Zheng S: B7-H1 up-regulated expression in human pancreatic carcinoma tissue associates with tumor progression. J Cancer Res Clin Oncol 2008, 134:1021-1027.

104. Nomi T, Sho M, Akahori T, Hamada K, Kubo A, Kanehiro H, Nakamura S, Enomoto K, Yagita H, Azuma M, Nakajima Y: Clinical significance and therapeutic potential of the programmed death-1 ligand/programmed death-1 pathway in human pancreatic cancer. Clin Cancer Res 2007, 13:2151-2157.

105. Krambeck AE, Dong $H$, Thompson $R H$, Kuntz SM, Lohse CM, Leibovich BC, Blute ML, Sebo TJ, Cheville JC, Parker AS, Kwon ED: Survivin and B7-H1 are collaborative predictors of survival and represent potential therapeutic targets for patients with renal cell carcinoma. Clin Cancer Res 2007, 13:1749-1756.

106. Thompson RH, Kuntz SM, Leibovich BC, Dong H, Lohse CM, Webster WS, Sengupta S, Frank I, Parker AS, Zincke H, Blute ML, Sebo TJ, Cheville JC, Kwon ED: Tumor B7-H1 is associated with poor prognosis in renal cell carcinoma patients with long-term follow-up. Cancer Res 2006, 66:3381-3385

107. Gao Q, Wang XY, Qiu SJ, Yamato I, Sho M, Nakajima Y, Zhou J, Li BZ, Shi YH, Xiao YS, Xu Y, Fan J: Overexpression of PD-L1 significantly associates with tumor aggressiveness and postoperative recurrence in human hepatocellular carcinoma. Clin Cancer Res 2009, 15:971-979.

108. Wu K, Kryczek I, Chen L, Zou W, Welling TH: Kupffer cell suppression of $\mathrm{CD}^{+} \mathrm{T}$ cells in human hepatocellular carcinoma is mediated by $\mathrm{B} 7-\mathrm{H} 1 /$ programmed death-1 interactions. Cancer Res 2009, 69:8067-8075.

109. Boorjian SA, Sheinin Y, Crispen PL, Farmer SA, Lohse CM, Kuntz SM, Leibovich BC, Kwon ED, Frank I: T-cell coregulatory molecule expression in urothelial cell carcinoma: clinicopathologic correlations and association with survival. Clin Cancer Res 2008, 14:4800-4808.

110. Konishi J, Yamazaki K, Azuma M, Kinoshita I, Dosaka-Akita H, Nishimura M: B7-H1 expression on non-small cell lung cancer cells and its relationship with tumor-infiltrating lymphocytes and their PD-1 expression. Clin Cancer Res 2004, 10:5094-5100.

111. Sun Y, Wang Y, Zhao J, Gu M, Giscombe R, Lefvert AK, Wang X: B7-H3 and B7-H4 expression in non-small-cell lung cancer. Lung Cancer 2006, 53:143-151.

112. Mugler KC, Singh M, Tringler B, Torkko KC, Liu W, Papkoff J, Shroyer KR: B7$\mathrm{H} 4$ expression in a range of breast pathology: correlation with tumor Tcell infiltration. Appl Immunohistochem Mol Morphol 2007, 15:363-370.

113. Tringler B, Zhuo S, Pilkington G, Torkko KC, Singh M, Lucia MS, Heinz DE, Papkoff J, Shroyer KR: B7-H4 is highly expressed in ductal and lobular breast cancer. Clin Cancer Res 2005, 11:1842-1848.

114. Miyatake T, Tringler B, Liu W, Liu SH, Papkoff J, Enomoto T, Torkko KC Dehn DL, Swisher A, Shroyer KR: B7-H4 (DD-O110) is overexpressed in high risk uterine endometrioid adenocarcinomas and inversely correlated with tumor T-cell infiltration. Gynecol Oncol 2007, 106:119-127.
115. Thompson $\mathrm{RH}$, Dong H, Kwon ED: Implications of B7-H1 expression in clear cell carcinoma of the kidney for prognostication and therapy. Clin Cancer Res 2007, 13(2 Pt 2):709s-715s.

116. Shi F, Shi M, Zeng Z, Qi RZ, Liu ZW, Zhang JY, Yang YP, Tien P, Wang FS: PD-1 and PD-L1 upregulation promotes CD8 ${ }^{+}$T-cell apoptosis and postoperative recurrence in hepatocellular carcinoma patients. Int $J$ Cancer 2011, 128:887-896.

117. Sfanos KS, Bruno TC, Meeker AK, De Marzo AM, Isaacs WB, Drake CG: Human prostate-infiltrating $\mathrm{CD}^{+} \mathrm{T}$ lymphocytes are oligoclonal and PD$1^{+}$. Prostate 2009, 69:1694-1703

118. Matsuzaki J, Gnjatic S, Mhawech-Fauceglia P, Beck A, Miller A, Tsuji T, Eppolito C, Qian F, Lele S, Shrikant P, Old LJ, Odunsi K: Tumor-infiltrating NY-ESO-1-specific CD8 ${ }^{+}$T cells are negatively regulated by LAG-3 and PD-1 in human ovarian cancer. Proc Natl Acad Sci USA 2010, 107:7875-7880

119. Zhang Y, Huang S, Gong D, Qin Y, Shen Q: Programmed death-1 upregulation is correlated with dysfunction of tumor-infiltrating $C D 8^{+} \mathrm{T}$ lymphocytes in human non-small cell lung cancer. Cell Mol Immunol 2010, 7:389-395.

120. Munn DH, Mellor AL: Indoleamine 2,3-dioxygenase and tumor-induced tolerance. J Clin Invest 2007, 117:1147-1154.

121. Ozaki Y, Edelstein MP, Duch DS: Induction of indoleamine 2,3dioxygenase: a mechanism of the antitumor activity of interferon gamma. Proc Natl Acad Sci USA 1988, 85:1242-1246.

122. Witkiewicz A, Williams TK, Cozzitorto J, Durkan B, Showalter SL, Yeo CJ, Brody JR: Expression of indoleamine 2,3-dioxygenase in metastatic pancreatic ductal adenocarcinoma recruits regulatory $T$ cells to avoid immune detection. J Am Coll Surg 2008, 206:849-854.

123. Pan K, Wang H, Chen MS, Zhang HK, Weng DS, Zhou J, Huang W, Li JJ, Song HF, Xia JC: Expression and prognosis role of indoleamine 2,3dioxygenase in hepatocellular carcinoma. J Cancer Res Clin Oncol 2008, 134:1247-1253.

124. Brandacher $G$, Perathoner $A$, Ladurner $R$, Schneeberger $S$, Obrist $P$, Winkler C, Werner ER, Werner-Felmayer G, Weiss HG, Göbel G, Margreiter R, Königsrainer A, Fuchs D, Amberger A: Prognostic value of indoleamine 2,3-dioxygenase expression in colorectal cancer: effect on tumorinfiltrating T cells. Clin Cancer Res 2006, 12:1144-1151.

125. Ino K, Yoshida N, Kajiyama H, Shibata K, Yamamoto E, Kidokoro K, Takahashi N, Terauchi M, Nawa A, Nomura S, Nagasaka T, Takikawa O, Kikkawa F: Indoleamine 2,3-dioxygenase is a novel prognostic indicator for endometrial cancer. Br J Cancer 2006, 95:1555-1561.

126. Takao M, Okamoto A, Nikaido T, Urashima M, Takakura S, Saito M, Saito M, Okamoto S, Takikawa O, Sasaki H, Yasuda M, Ochiai K, Tanaka T: Increased synthesis of indoleamine-2,3-dioxygenase protein is positively associated with impaired survival in patients with serous-type, but not with other types of, ovarian cancer. Oncol Rep 2007, 17:1333-1339.

127. Yoshida N, Ino K, Ishida Y, Kajiyama H, Yamamoto E, Shibata K, Terauchi M, Nawa A, Akimoto H, Takikawa O, Isobe K, Kikkawa F: Overexpression of indoleamine 2,3-dioxygenase in human endometrial carcinoma cells induces rapid tumor growth in a mouse xenograft model. Clin Cancer Res 2008, 14:7251-7259.

128. Wu G, Morris SM Jr: Arginine metabolism: nitric oxide and beyond. Biochem J 1998, 336(Pt 1):1-17.

129. Rodriguez PC, Zea AH, Culotta KS, Zabaleta J, Ochoa JB, Ochoa AC: Regulation of $\mathrm{T}$ cell receptor CD3zeta chain expression by L-arginine. J Biol Chem 2002, 277:21123-21129.

130. Rodriguez PC, Zea AH, DeSalvo J, Culotta KS, Zabaleta J, Quiceno DG, Ochoa JB, Ochoa AC: L-arginine consumption by macrophages modulates the expression of CD3 zeta chain in T lymphocytes. $J$ Immunol 2003, 171:1232-1239.

131. Harris BE, Pretlow TP, Bradley EL Jr, Whitehurst GB, Pretlow TG: Arginase activity in prostatic tissue of patients with benign prostatic hyperplasia and prostatic carcinoma. Cancer Res 1983, 43:3008-3012.

132. Shukla VK, Tandon A, Ratha BK, Sharma D, Singh TB, Basu S: Arginase activity in carcinoma of the gallbladder: a pilot study. Eur J Cancer Prev 2009, 18:199-202.

133. Rotondo R, Mastracci L, Piazza T, Barisione G, Fabbi M, Cassanello M, Costa R, Morandi B, Astigiano S, Cesario A, Sormani MP, Ferlazzo G, Grossi F, Ratto GB, Ferrini S, Frumento G: Arginase 2 is expressed by human lung cancer, but it neither induces immune suppression, nor affects disease progression. Int J Cancer 2008, 123:1108-1116. 
134. Suer Gokmen S, Yoruk Y, Cakir E, Yorulmaz F, Gulen S: Arginase and ornithine, as markers in human non-small cell lung carcinoma. Cancer Biochem Biophys 1999, 17:125-131.

135. Bronte V, Kasic T, Gri G, Gallana K, Borsellino G, Marigo I, Battistini L, lafrate M, Prayer-Galetti T, Pagano F, Viola A: Boosting antitumor responses of T lymphocytes infiltrating human prostate cancers. J Exp Med 2005, 201:1257-1268.

136. Esendagli G, Bruderek K, Goldmann T, Busche A, Branscheid D, Vollmer E, Brandau S: Malignant and non-malignant lung tissue areas are differentially populated by natural killer cells and regulatory T cells in non-small cell lung cancer. Lung Cancer 2008, 59:32-40.

137. Griffiths RW, Elkord E, Gilham DE, Ramani V, Clarke N, Stern PL, Hawkins RE: Frequency of regulatory $T$ cells in renal cell carcinoma patients and investigation of correlation with survival. Cancer Immunol Immunother 2007, 56:1743-1753.

138. Hiraoka N, Onozato K, Kosuge T, Hirohashi S: Prevalence of FOXP3 ${ }^{+}$ regulatory $T$ cells increases during the progression of pancreatic ductal adenocarcinoma and its premalignant lesions. Clin Cancer Res 2006, 12:5423-5434.

139. Kobayashi N, Hiraoka N, Yamagami W, Ojima H, Kanai Y, Kosuge T, Nakajima A, Hirohashi S: FOXP3 ${ }^{+}$regulatory T cells affect the development and progression of hepatocarcinogenesis. Clin Cancer Res 2007, 13:902-911.

140. Liyanage UK, Moore $\Pi$, Joo HG, Tanaka Y, Herrmann V, Doherty G, Drebin JA, Strasberg SM, Eberlein TJ, Goedegebuure PS, Linehan DC: Prevalence of regulatory $T$ cells is increased in peripheral blood and tumor microenvironment of patients with pancreas or breast adenocarcinoma. J Immunol 2002, 169:2756-2761.

141. Schwarz S, Butz M, Morsczeck C, Reichert TE, Driemel O: Increased number of CD25 FoxP3 regulatory $T$ cells in oral squamous cell carcinomas detected by chromogenic immunohistochemical double staining. J Oral Pathol Med 2008, 37:485-489.

142. Siddiqui SA, Frigola X, Bonne-Annee S, Mercader M, Kuntz SM, Krambeck AE, Sengupta S, Dong H, Cheville JC, Lohse CM, Krco CJ: Tumorinfiltrating Foxp $3^{-} \mathrm{CD} 4^{+} \mathrm{CD} 25^{+} \mathrm{T}$ cells predict poor survival in renal cell carcinoma. Clin Cancer Res 2007, 13:2075-2081.

143. Viehl CT, Moore TT, Liyanage UK, Frey DM, Ehlers JP, Eberlein TJ, Goedegebuure PS, Linehan DC: Depletion of $C D 4^{+} \mathrm{CD} 25^{+}$regulatory $\mathrm{T}$ cells promotes a tumor-specific immune response in pancreas cancerbearing mice. Ann Surg Oncol 2006, 13:1252-1258.

144. Kaporis HG, Guttman-Yassky E, Lowes MA, Haider AS, Fuentes-Duculan J, Darabi K, Whynot-Ertelt J, Khatcherian A, Cardinale I, Novitskaya I, Krueger JG, Carucci JA: Human basal cell carcinoma is associated with Foxp $3^{+} \mathrm{T}$ cells in a Th2 dominant microenvironment. J Invest Dermatol 2007, 127:2391-2398.

145. Sharma S, Yang SC, Zhu L, Reckamp K, Gardner B, Baratelli F, Huang M, Batra RK, Dubinett SM: Tumor cyclooxygenase-2/prostaglandin E2dependent promotion of FOXP3 expression and CD4 $4^{+} \mathrm{CD} 25^{+} \mathrm{T}$ regulatory cell activities in lung cancer. Cancer Res 2005, 65:5211-5220.

146. Curiel TJ, Coukos G, Zou L, Alvarez X, Cheng P, Mottram P, EvdemonHogan M, Conejo-Garcia JR, Zhang L, Burow M, Zhu Y, Wei S, Kryczek I, Daniel B, Gordon A, Myers L, Lackner A, Disis ML, Knutson KL, Chen L, Zou W: Specific recruitment of regulatory $T$ cells in ovarian carcinoma fosters immune privilege and predicts reduced survival. Nat Med 2004, 10:942-949.

147. Tan MC, Goedegebuure PS, Belt BA, Flaherty B, Sankpal N, Gillanders WE, Eberlein TJ, Hsieh CS, Linehan DC: Disruption of CCR5-dependent homing of regulatory $T$ cells inhibits tumor growth in a murine model of pancreatic cancer. J Immunol 2009, 182:1746-1755.

148. Almand B, Resser JR, Lindman B, Nadaf S, Clark Jl, Kwon ED, Carbone DP, Gabrilovich DI: Clinical significance of defective dendritic cell differentiation in cancer. Clin Cancer Res 2000, 6:1755-1766.

149. Garrity T, Pandit R, Wright MA, Benefield J, Keni S, Young MR: Increased presence of $\mathrm{CD}_{3} 4^{+}$cells in the peripheral blood of head and neck cancer patients and their differentiation into dendritic cells. Int J Cancer 1997, 73:663-669.

150. Schmielau J, Finn OJ: Activated granulocytes and granulocyte-derived hydrogen peroxide are the underlying mechanism of suppression of tcell function in advanced cancer patients. Cancer Res 2001, 61:4756-4760.

151. Bluth MJ, Zaba LC, Moussai D, Suarez-Farinas M, Kaporis H, Fan L, Pierson KC, White TR, Pitts-Kiefer A, Fuentes-Duculan J, Guttman-Yassky E,
Krueger JG, Lowes MA, Carucci JA: Myeloid dendritic cells from human cutaneous squamous cell carcinoma are poor stimulators of T-cell proliferation. J Invest Dermatol 2009, 129:2451-2462.

152. Pak AS, Wright MA, Matthews JP, Collins SL, Petruzzelli GJ, Young MR: Mechanisms of immune suppression in patients with head and neck cancer: presence of $\mathrm{CD} 34^{+}$cells which suppress immune functions within cancers that secrete granulocyte-macrophage colony-stimulating factor. Clin Cancer Res 1995, 1:95-103.

153. Young MR, Wright MA, Lozano Y, Matthews JP, Benefield J, Prechel MM: Mechanisms of immune suppression in patients with head and neck cancer: influence on the immune infiltrate of the cancer. Int J Cancer 1996, 67:333-338.

154. Young MR, Wright MA, Lozano Y, Prechel MM, Benefield J, Leonetti JP, Collins SL, Petruzzelli GJ: Increased recurrence and metastasis in patients whose primary head and neck squamous cell carcinomas secreted granulocyte-macrophage colony-stimulating factor and contained CD34 natural suppressor cells. Int J Cancer 1997, 74:69-74.

155. Norian LA, Rodriguez PC, O'Mara LA, Zabaleta J, Ochoa AC, Cella M, Allen PM: Tumor-infiltrating regulatory dendritic cells inhibit $\mathrm{CD}^{+} \mathrm{T}$ cell function via L-arginine metabolism. Cancer Res 2009, 69:3086-3094.

156. Hoechst B, Voigtlaender T, Ormandy L, Gamrekelashvili J, Zhao F, Wedemeyer H, Lehner F, Manns MP, Greten TF, Korangy F: Myeloid derived suppressor cells inhibit natural killer cells in patients with hepatocellular carcinoma via the NKp30 receptor. Hepatology 2009, 50:799-807.

157. Kusmartsev S, Su Z, Heiser A, Dannull J, Eruslanov E, Kubler H, Yancey D, Dahm P, Vieweg J: Reversal of myeloid cell-mediated immunosuppression in patients with metastatic renal cell carcinoma. Clin Cancer Res 2008, 14:8270-8278.

158. Zea AH, Rodriguez PC, Atkins MB, Hernandez C, Signoretti S, Zabaleta J, McDermott D, Quiceno D, Youmans A, O'Neill A, Mier J, Ochoa AC: Arginase-producing myeloid suppressor cells in renal cell carcinoma patients: a mechanism of tumor evasion. Cancer Res 2005, 65:3044-3048.

159. Hoechst B, Ormandy LA, Ballmaier M, Lehner F, Kruger C, Manns MP, Greten TF, Korangy F: A new population of myeloid-derived suppressor cells in hepatocellular carcinoma patients induces $C D 4^{+} \mathrm{CD} 25^{+} \mathrm{Foxp}^{+} \mathrm{T}$ cells. Gastroenterology 2008, 135:234-243.

doi:10.1186/1756-9966-30-12

Cite this article as: Du and Wang: The immunoregulatory mechanisms of carcinoma for its survival and development. Journal of Experimental \& Clinical Cancer Research 2011 30:12.

\section{Submit your next manuscript to BioMed Central and take full advantage of:}

- Convenient online submission

- Thorough peer review

- No space constraints or color figure charges

- Immediate publication on acceptance

- Inclusion in PubMed, CAS, Scopus and Google Scholar

- Research which is freely available for redistribution

Submit your manuscript at www.biomedcentral.com/submit
Biomed Central 